\title{
Pemanfaatan potensi lokal buah Nanas untuk meningkatkan perekonomian keluarga di Kecamatan Bangko Pusako Kabupaten Rokan Hilir
}

\author{
Meilda Wiguna, Hardi, Dasrol, Sem Paulus Silalahi1, Mudrika Alamsyah Hasan, Astrid \\ Faradisty*, \& Isma Mulyani \\ Universitas Riau \\ * astrid.faradisty@lecturer.unri.ac.id
}

\begin{abstract}
Abstrak. Bangko pusako adalah sebuah kecamatan di Kabupaten Rokan Hilir, Riau. Mata pencaharian sebagian besar penduduknya adalah sebagai buruh tani kelapa sawit dan petani buah nanas. Dalam mengelola potensi lokal tidak bisa terlepas dari pengetahuan untuk mengelola usaha tersebut, ini tentunya diperoleh melalui pemahaman akan bisnis/usaha yang dijalankan tersebut, aturan-aturan yang melekat di dalam melaksanakan usaha tersebut, serta pelaporan keuangan sederhana dalam mengelola bisnis atau usaha dalam mengembangkan potensi lokal suatu daerah yang akan kita jalankan menjadi peluang potensi usaha. Kegiatan pengabdian kepada masyarakat ini bertujuan untuk meningkatkan pengetahuan masyarakat Kecamatan bangko pusako khususnya bagi ibu rumah tangga istri buruh tani sawit dan anak perempuannya tentang diversifikasi buah nanas menjadi produk olahan yaitu selai nanas dan dodol nanas. Tujuan lain adalah pembekalan jiwa entrepreneurship, hukum bisnis, analisis daya saing produk olahan nanas, dan pelatihan penyajian laporan keuangan sederhana dalam mengelola usaha diversifikasi produk olahan nanas tersebut. Sehingga dapat meningkatkan kesejahteraan perekonomian keluarga di desa-desa yang ada di kecamatan bangko pusako, kabupaten rokan hilir. Dari hasil evaluasi program yang dilaksanakan sudah ada beberapa ibu-ibu yang membuat selai nanas dan menjualnya ke tetangga berdasarkan pesanan untuk selai kue dan ada juga yang menjual dodol nanas ke sekolah sekolah yang dikemas dalam plastik kecil.
\end{abstract}

Kata Kunci: potensi lokal, nenas, istri buruh tani sawit, perekonomian keluarga

\begin{abstract}
Bangko Pusako is a sub-district in district Rokan Hilir, Riau. Mostly the native works as palm oil farm workers and pineapple farmer.Regardless, people need the knowledge to manage local potensial through understanding about business they'll gonna run, the law, and also simple financial report to develop local potensial becoming potensial business. This program (communities devotion) has a goal to enhancing knowledge of society in Bangko Pusako, especially housewife and daughter of palm oil farm worker, about how pineapple fruit is processed as jam and dodol (traditional food of Indonesia) by diversification. Other goals include entrepreneurship foundation, business law, competitiveness analysis of processed pineapple products, and simply financial report's training in term to manage business processed pineapple product diversification. So that it can improve the economic welfare of the family in the villages in the Bangko Pusako sub-district, Rokan Hilir district. From the results of the program evaluation, there have been several mothers who make pineapple jam and sell it to neighbors based on orders for cake jam and some sell lunkhead pineapple to schools which are packaged in small plastic.
\end{abstract}

Key Words: local potensial, pineapple fruit, housewife of palm oil farm worker, family economy

To cite this article: Wiguna, M., Hardi., Dasrol., S. P. Silalahi., M. A. Hasan., A. Faradisty., \& I. Mulyani. 2020. Pemanfaatan potensi lokal buah Nanas untuk meningkatkan perekonomian keluarga di Kecamatan Bangko Pusako Kabupaten Rokan Hilir. Unri Conference Series: Community Engagement 2: 471-477. https://doi.org/10.31258/unricsce.2.471-477

(C) 2020 Authors

Peer-review under responsibility of the organizing committee of Seminar Nasional Pemberdayaan Masyarakat 2020 


\section{PENDAHULUAN}

Pertambahan penduduk dari tahun ke tahun akan membuka peluang usaha dalam variasi penggunaan makanan, salah satu adalah makanan yang bersalah dari potensi lokal suatu daerah seperti yang terdapat di kecamatan bangko pusako ini adalah potensi buah lokal nanas. Diversifikasi produk olahan buah lokal memiliki prospek yang baik dalam upaya meningkatkan kesejahteraan masyarakat setempat dalam hal ini keluarga atau masyarakat kecamatan bangko pusako yang sebagian besar berprofesi sebagai buruh tani kelapa sawit. Adanya anggota keluarga buruh tani sawit (istri dan anak perempuan yang sudah cukup umur) untuk mengembangkan usaha diversifikasi produk olahan buah nanas yang merupakan potensi buah lokal yang sangat banyak dihasilkan di kecamatan bangko pusako ini merupakan peluang yang baik dalam upaya meningkatkan perekonomian buruh tani sawit di kecamatan bangko pusako, selain itu dibutuhkan dibutuhkan pula penerapan Cara Produksi Pangan Yang Baik (CPPB) agar selain bernilai materi cita rasa dan gizi dalam potensi lokal yang akan digali tetap terjaga.

Dalam mengelola potensi lokal tidak bisa terlepas dari pengetahuan untuk mengelola usaha tersebut menjadi bisnis yang berkembang dari waktu ke waktu dengan profit yang semakin meningkat, ini tentunya diperoleh melalui pemahaman akan bisnis/usaha yang dijalankan tersebut, aturan-aturan yang melekat di dalam melaksanakan usaha tersebut (hukum bisnis) serta pelaporan keuangan sederhana dalam mengelola bisnis atau usaha dalam mengembangkan potensi lokal suatu daerah yang akan kita jalankan menjadi peluang potensi usaha.

Berhasil atau tidaknya pembangunan suatu daerah sangat dipengaruhi oleh sumber daya manusia yang dimilikinya. Semakin maju pendidikan akan meningkatkan sumber daya manusia yang dimiliki oleh daerah tersebut. Demikian pentingnya peranan pendidikan, maka sudah sewajarnya pemerintah dan seluruh lapisan masyarakat memberikan perhatian yang besar pada bidang ini. Pendidikan tidak hanya diperoleh melalui pendidikan formal namun bisa juga melalui keikutsertaan masyarakat di kegiatan pelatihan-pelatihan ataupun penyuluhan yang dilakukan oleh perguruan tinggi. Salah satunya kegiatan yang akan diselenggarakan oleh tim pengabdian masyarakat universitas riau ini yang merupakan implementasi dari pelaksanaan salah satu dari tridarma perguruan tinggi.

Peningkatan jumlah penduduk dan aktivitas di kawasan ini akan berdampak terhadap perekonomian daerah tersebut tersebut. Program bina desa kecamatan bangko pusako tentang "pemanfaatan potensi lokal buah nanas bagi ibu-ibu rumah tangga buruh tani sawit di kecamatan bangko pusako" penting dilakukan sebagai salah satu cara untuk memberi pengetahuan kepada masyarakat tentang bagaimana upaya peningkatan perekonomian keluarga.

\section{Tinjauan pustaka}

Nanas menjadi salah satu komoditas tanaman yang banyak dimanfaatkan buahnya untuk olahan makanan. Selain nikmat dimakan secara langsung, buah nanas kerap diolah dalam berbagai jenis makanan. Banyak perusahaan dan pabrik besar yang membutuhkan pasokan buah nanas dalam besar. Buah nanas ini kerap dijadikan olahan makanan mulai dari keripik, selai, sirup, sari buah dan olahan lainnya. Peluang usaha budidaya nenas memang sangat menjanjikan. Dimana budidaya nanas memiliki peluang yang masih terbuka lebar. Keuntungan yang didapatkan dalam budidaya nanas memang mampu menghasilkan keuntungan yang bernilai besar. Dalam bisnis budidaya nanas membutuhkan beberapa peralatan penting diantaranya pengadaan bibit nanas, cangkul, keranjang panen nanas, timbangan, pompa air, hand sprayer, gerobak dorong, sewa lahan, golok dan sabit, timba, selang air dan gunting. Dengan adanya peralatan tersebut maka bisnis budidaya nanas makin maksimal.

Dalam menjalankan usaha tersebut Penting juga memahami Badan Hukum Bagi Usaha Kecil \& Menengah. Sudah bukan rahasia umum lagi jika UKM memang memegang peranan penting dalam pertumbuhan ekonomi nasional. Sektor UKM merupakan sektor terbesar dan sudah terbukti mampu bertahan dari berbagai permasalahan dan guncangan ekonomi dunia.

Hal yang tak kalah penting dalam mengelola usaha adalah memiliki jiwa entrepreneurship. Menurut Thomas W. Zimmerer (2008) entrepreneurship (kewirausahaan) adalah penerapan kreativitas dan keinovasian untuk memecahkan permasalahan dan upaya memanfaatkan peluang-peluang yang dihadapi orang setiap hari.

Menurut Andrew J. Dubrin (2008) entrepreneur adalah seseorang yang mendirikan dan menjalankan sebuah usaha yang inovatif. Istilah entrepreneurship (kewirausahaan) pada dasarnya merupakan suatu disiplin ilmu yang mempelajari tentang nilai, kemampuan (ability) dan perilaku seseorang dalam menghadapi tantangan hidup untuk memperoleh peluang dengan berbagai risiko yang mungkin dihadapinya. Secara umum tahaptahap dalam melakukan entrepreneurship: 
a. Tahap memulai

b. Tahap melaksanakan usaha

c. Tahap mempertahankan usaha

d. Tahap mengembangkan usaha

Proses entrepreneurship diawali dengan suatu aksioma, yaitu adanya tantangan. Dari tantangan tersebut timbul gagasan, kemauan dan dorongan untuk berinisiatif, yang tidak lain adalah berfikir kreatif dan bertindak inovatif sehingga tantangan tadi teratasi dan terpecahkan. Semua tantangan pasti memiliki risiko, yaitu kemungkinan berhasil atau tidak berhasil. Oleh sebab itu entrepreneur adalah seorang yang berani menghadapi risiko dan menyukai tantangan (Suryana, 2006).

Kegagalan dan keberhasilan usaha seorang entrepreneur ditentukan oleh beberapa faktor, antara lain :

a. Faktor pemasaran

b. Faktor manusia (SDM)

c. Faktor keuangan

d. Faktor organisasi

e. Faktor perencanaan

f. Faktor lokasi/pasar

g. Faktor kreativitas

h. Faktor lapangan

Konsep dan strategi menjalankan usaha sangat tergantung pada bagaimana kita menyikapi dan menarik sisi positif dari faktor-faktor keberhasilan sebuah usaha. (Hendro, 2011). Selanjutnya jika kita melakukan usaha tak terlepas bahwa kita wajib tahu dan memahami laporan keuangan sederhana (pembukuan), hal tersebut bertujuan untuk pengendalian keuangannya. Pengertian dari pembukuan secara umum adalah proses pencatatan yang mengumpulkan semua informasi dan data yang berkaitan dengan laporan keuangan. Sebagian besar bagi para pengusaha baru melupakan pembukuan karena hanya berfokus kepada penjualan produk dan jasa agar pemasaran cepat meluas.

Risiko yang dapat terjadi apabila dalam setiap usaha tidak dilakukan pencatatan adalah munculnya kecurangan yang berkaitan dengan keuangan, laporan yang tidak jelas apabila menginginkan adanya penambahan modal melalui investor maupun bank, kesulitan pengambilan keputusan di situasi mendesak yang berkaitan dengan keuangan. Sehingga pada saat usaha mulai berjalan sebaiknya disertai pula pembukuan yang bisa dilakukan tiap hari dan pada saat akhir tahun dilakukan perhitungan total agar mendapatkan informasi pencapaian hasil dalam setahun. Di bawah ini merupakan langkah-langkah sederhana yang bisa anda ikuti dalam membuat pembukuan bisnis yang sederhana :

Memiliki catatan untuk semua transaksi pengeluaran

1. Catatan untuk semua transaksi pemasukan

2. Estimasi arus kas

3. Data dan catatan semua barang inventaris

\section{METODE PENERAPAN}

Kegiatan pengabdian kepada masyarakat di Kecamatan Bangko Pusako ini dilakukan dengan cara Diversifikasi Usaha Hasil olahan buah lokal yaitu buah nanas. Kegiatan penyuluhan ini dilakukan melalui empat tahap, yaitu survey lokasi, penyuluhan dengan materi-materi, praktek pembuatan selai nanas dan dodol nenas, serta evaluasi.

Kegiatan akan dilakukan dalam 4 kali kunjungan ke Kecamatan Bangko Pusako.

1. Kunjungan Pertama survey lokasi, identifikasi masalah, penetapan peserta pelatihan, ceramah tentang pentingnya memanfaatkan peluang usaha untuk peningkatan ekonomi keluarga dengan memanfaatkan potensi buah lokal, analisis ekonomi usaha diversifikasi produk olahan buah lokal. Informasi pentingnya laporan keuangan sederhana.

2. Kunjungan kedua Pelatihan pembekalan jiwa entrepreneurship, pemahaman hukum bisnis produk, serta Pelatihan penyajian laporan keuangan sederhana.

3. Kunjungan ketiga Pelatihan pembuatan selai nanas dan dodol nanas.

4. Kunjungan keempat Evaluasi program yang sudah dilakukan. 


\section{HASIL DAN KETERCAPAIAN SASARAN}

Kegiatan pengabdian kepada masyarakat desa binaan ini dilaksanakan di empat desa yang ada di kecamatan bangko pusako kabupaten Rokan Hilir. Adapun desa yang berpartisipasi dalam rangkaian kegiatan pengabdian tersebut mulai dari kegiatan pelatihan pembekalan jiwa entrepreneurship, pemahaman hukum bisnis produk, serta pelatihan penyajian laporan keuangan sederhana sampai pada tahap kegiatan praktek pembuatan selai nanas dan dodol nanas adalah desa bangko kanan, desa bangko pusako, desa bangko makmur dan desa bangko lestari, keempat desa ini termasuk dari beberapa desa yang dijadikan kukerta 2019 di kecamatan bangko pusako kabupaten rokan hilir.

Kelompok masyarakat yang menjadi peserta kegiatan terdiri dari ibu-ibu rumah tangga istri dari buruh tani sawit, remaja putri, perangkat dari masing-masing desa (Ibu RT/RW) ibu-ibu PKK di empat desa tersebut, ibu ketua PKK desa bangko kanan, desa bangko pusako, desa bangko makmur dan desa bangko serta ibu camat bangko pusako yang juga sebagai ketua PKK se kecamatan bangko pusako yang menjadi mitra dari kegiatan Pengabdian Masyarakat desa binaan ini.

Kegiatan pengabdian kepada masyarakat desa binaan ini dilakukan dengan empat tahapan, tahapan pertama tentunya survey untuk menentukan mitra dan masyarakat sasaran kegiatan pengabdian. Selanjutnya tahapan kedua kegiatan pelatihan pembekalan jiwa entrepreneurship, pemahaman hukum bisnis produk, serta Pelatihan penyajian laporan keuangan sederhana, tahapan ketiga praktikum pembuatan selai nanas dan dodol nanas dan terakhir tahapan ke empat tahap kegiatan evaluasi.

Adapun tempat diselenggarakan nya dua kegiatan utama yaitu 1: pelatihan pembekalan jiwa entrepreneurship, pemahaman hukum bisnis produk, serta Pelatihan penyajian laporan keuangan sederhana, 2: Praktek pembuatan selai nanas dan dodol nanas serta diskusi adalah di aula kantor camat kecamatan bangko pusako.

Kegiatan utama yang pertama yaitu pelatihan pembekalan jiwa entrepreneurship, pemahaman hukum bisnis produk, serta Pelatihan penyajian laporan keuangan sederhana, dilaksanakan pada tanggal 13 juli 2019 sedangkan kegiatan yang utama yang kedua berupa praktek pembuatan selai nanas dan dodol nanas dilaksanakan pada tanggal 3 Agustus 2019 penetapan tanggal ini tentunya atas kesepakatan dengan para mitra di masing-masing desa, perangkat desa dan tentunya peserta yang menjadi sasaran dari pengabdian kepada masyarakat desa binaan ini.

Kegiatan pengabdian kepada masyarakat ini tentunya melibatkan mahasiswa kukerta 2019 universitas riau yang berada di empat desa tersebut yaitu mahasiswa kukerta 2019 yang berada di desa bangko kanan, mahasiswa kukerta yang berada di bangko pusaka, mahasiswa yang ada di desa bangko makmur serta mahasiswa yang ada di desa bangko lestari. Semua peserta dalam kegiatan pengabdian masyarakat ini berada di aula satu hari yang dilaksanakan dari jam 8.00 sampai dengan pukul 16.00 baik itu pada tanggal 13 juli 2019 maupun kegiatan yang berlangsung pada tanggal 3 Agustus 2019.

Desa-desa yang ada di kecamatan bangko pusako kabupaten rokan hilir sangat berpotensi untuk dikembangkan menjadi desa binaan produk potensi buah lokal nanas, hal ini terbukti dari hasil survey dan wawancara yang kami tim lakukan dengan mitra maupun dari hasil pantauan langsung dilapangan. Dilihat dari suburnya buah nanas yang hidup di pekarangan rumah warga hal ini sangat berpotensi dikembangkan menjadi produk olahan yang siap dijual dengan harga yang jauh lebih tinggi.

Sementara itu berdasarkan wawancara dengan mitra serta masyarakat sasaran selama ini nanas dipanen dan langsung dijual tanpa diproses sebelumnya menjadi produk olahan, belum pernah ada penyuluhan-penyuluhan terkait diversifikasi buah nanas menjadi produk olahan yaitu selai nanas dan dodol nanas, dan belum pernah juga masyarakat di bangko pusako mengikuti penyuluhan seperti pembekalan jiwa entrepreneurship, hukum bisnis, analisis daya saing produk olahan nanas, dan pelatihan penyajian laporan keuangan sederhana dalam mengelola usaha diversifikasi produk olahan nanas tersebut.

Dari segi mata pencaharian sebagian besar Istri dan anak perempuan buruh perkebunan kelapa sawit tersebut tidak memiliki pekerjaan untuk menambah penghasilan keluarga, karena minimnya pengetahuan dan keahlian untuk membuat usaha sampingan dalam upaya menambah penghasilan keluarga. Padahal di satu sisi istri dan anak perempuan buruh tani tersebut memiliki waktu yang bisa dikembangkan untuk memperoleh penghasilan tambahan bagi keluarga.

Melihat harga sawit yang semakin menurun tentunya berdampak kepada penghasilan buruh tani tersebut. Akan berbeda kondisinya jika istri dan anak perempuan buruh tani tersebut bisa melakukan diversifikasi terhadap buah nanas yang banyak kita jumpai di kecamatan bangko pusako, sehingga akan mampu membantu meningkatkan kesejahteraan keluarganya. 


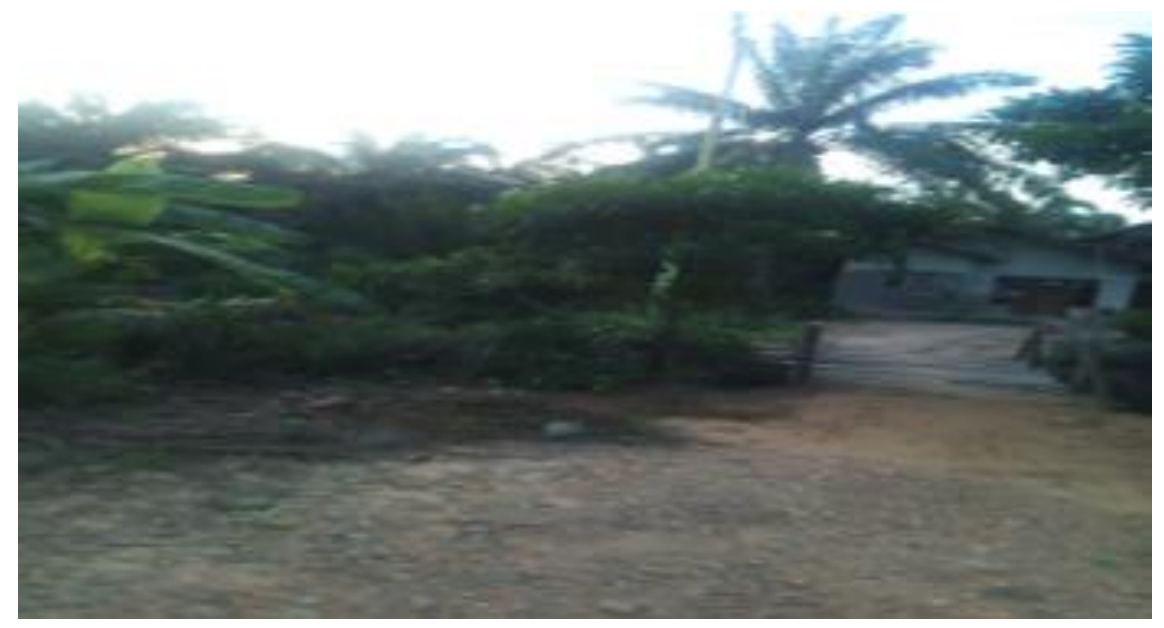

Gambar 1. Tanaman nanas yang belum dikelola dengan baik di pekarangan rumah

Kegiatan pengabdian masyarakat yang kami lakukan sangat memberikan solusi bagi pengembangan (pemberdayaan) masyarakat setempat. Dari beberapa rangkaian kegiatan yang kami lakukan tentunya membuka cakrawala berpikir dan pengetahuan bagi masyarakat yang mengikuti kegiatan pelatihan-pelatihan tersebut, sehingga efek atau perubahan pola berpikir akan tercermin dengan beberapa gagasan mereka untuk membentuk usaha pengolahan potensi lokal buah nanas. Hal ini terbukti dari beberapa gagasan dari para peserta yaitu:

- Perlu dilakukan pelatihan lebih lanjut

- Perlu dilakukan pelatihan terkait pemasaran potensi buah lokal yang baik

- Perlu dibentuk pengelolaan yang lebih efektif terkait struktur organisasi pengelolaan potensi lokal buah nanas

- Pelatihan pengemasan produk

- Pelatihan pengolahan buah nanas lainnya

- Perencanaan keuangan organisasi

- Jangkauan semua desa yang ada di kecamatan bangko pusako

Untuk mengetahui apakah kegiatan ini berjalan dengan baik maka, dilakukan evaluasi yang terdiri atas:

1. Evaluasi Program

Evaluasi program dimaksudkan untuk melihat secara empiris program yang diajukan dengan kondisi yang ada pada objek program pelatihan/penyuluhan . wawancara dengan mitra dan perangkat desa dan kelompok masyarakat yang menjadi khalayak sasaran untuk mengetahui sejauh mana tingkat pemahaman mereka mengenai tujuan yang ingin kita capai.

2. Evaluasi Proses

Evaluasi proses dimaksudkan untuk menilai kemanfaatan dan keberlangsungan program sesuai dengan tujuan dilaksanakannya program. Melalui wawancara lisan kepada peserta untuk mengetahui manfaat pelatihan yang dilakukan oleh penyelenggara. Serta juga dengan cara setelah pelatihan atau materi dan penjelasan disampaikan, peserta diberikan pertanyaan terkait materi yang telah disampaikan.

3. Evaluasi Hasil

Evaluasi hasil dimaksudkan untuk menilai kemanfaatan dan keberlangsungan program sesuai dengan tujuan dilaksanakannya program. Dengan cara melakukan evaluasi setelah dilakukan kegiatan pada tanggal 13 Juli 2019 dan tanggal 3 Agustus 2019. Evaluasi ini dilaksanakan pada tanggal 30 Agustus 2019. Secara rinci dipaparkan berikut ini: yaitu Implementasinya adalah dari tahap survei, berlanjut ke pelatihan pembekalan jiwa entrepreneurship, pemahaman hukum bisnis produk, serta Pelatihan penyajian laporan keuangan sederhana), kemudian praktikum pembuatan selai nanas dan dodol nanas dan terakhir evaluasi. Didapati bahwa program ini tercapai sesuai target, dari wawancara dengan camat, ketua PKK desa bangko kanan, ketua PKK desa bangko makmur, ketua PKK bangko pusaka dan ketua PKK bangko lestari dan beberapa peserta pelatihan bahwa mereka belum pernah mengikuti beberapa rangkain pelatihan yang kami lakukan sehingga setelah mengikuti pelatihan dan sekaligus praktek pengolahan potensi lokal buah nanas ini sangat memberikan tambahan pengetahuan dan ide-ide yang baru bagi mereka dan keinginan untuk 
melakukan pengembangan potensi lokal buah nanas sangat kuat, ditambah lagi kami menyampaikan bahwa program ini akan berlanjut pada tahun kedua dan ketiga sampai desa yang ada di kecamatan bangko pusako ini menjadi desa binaan Universitas Riau. Hal ini tentunya menjadi motivasi bagi mereka untuk menghasilkan produk olahan buah nanas yang nantinya akan sangat berpengaruh terhadap pendapatan keluarga yang tentunya akan berdampak pula terhadap kesejahteraan anggota keluarganya.

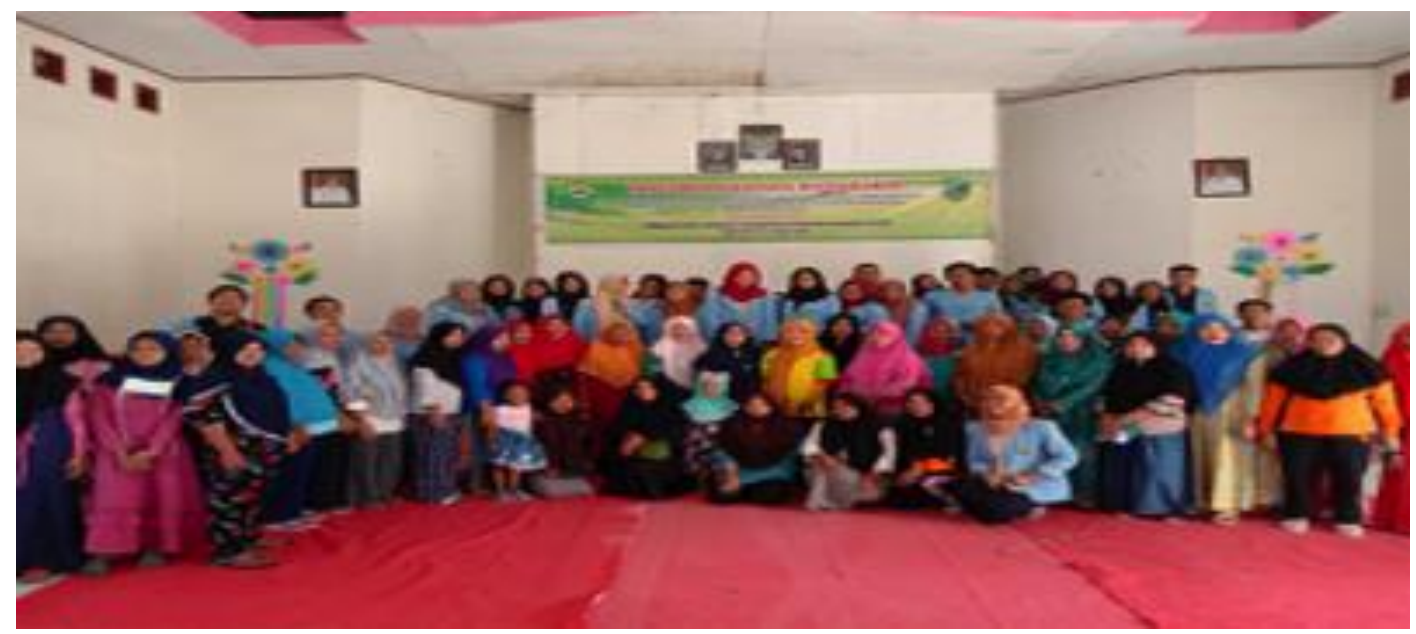

Gambar 2. Kegiatan ke 2. Pelatihan Dan Pembekalan Jiwa Entrepreneurship, Pemahaman Hukum Bisnis Produk, Serta Pelatihan Penyajian Laporan Keuangan Sederhana.

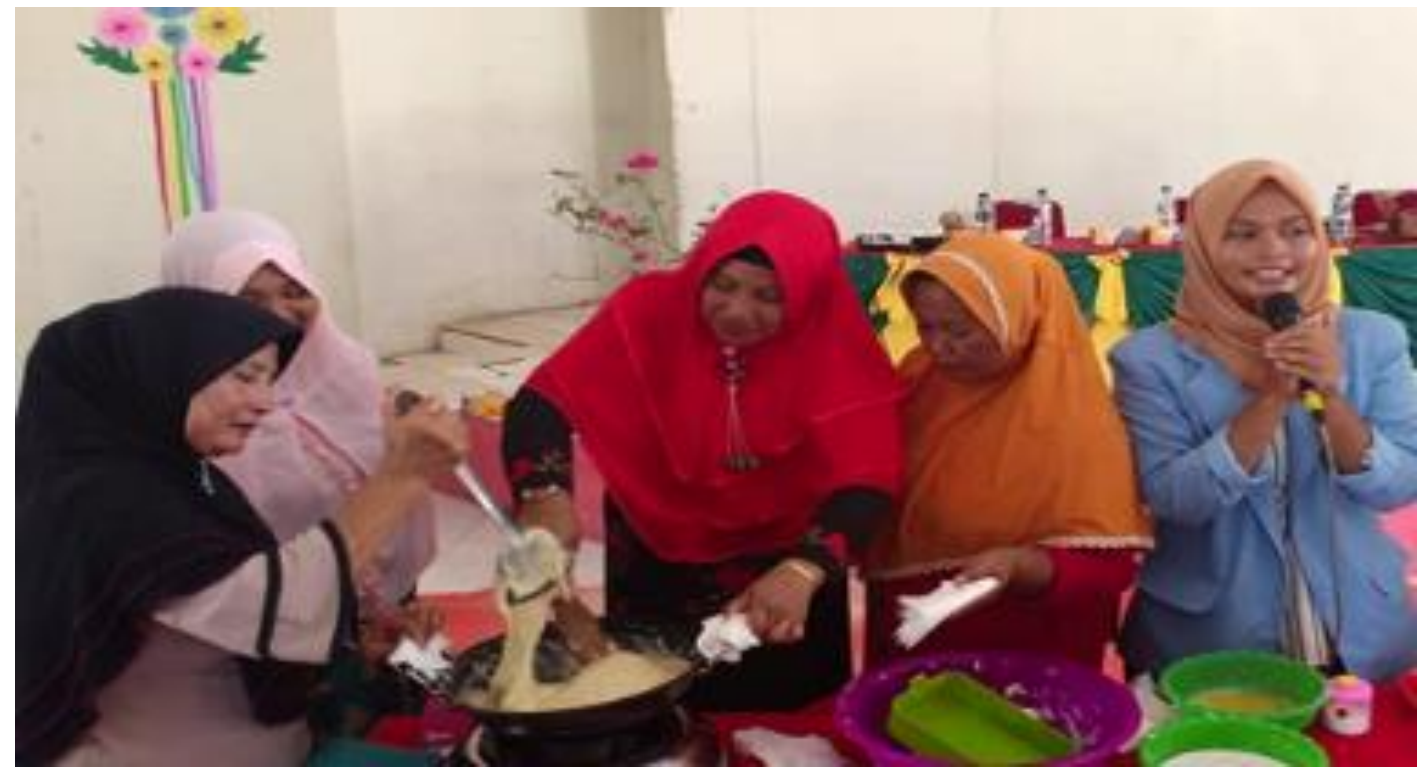

Gambar 3. Kegiatan ke 3 PM Praktek Pembuatan Selai Nanas dan Dodol Nanas

\section{KESIMPULAN}

Program pengabdian kepada masyarakat yang dilaksanakan di kecamatan bangko pusako dengan melibatkan 4 desa atau kepenghuluan yaitu desa yaitu desa bangko kanan, desa bangko pusako, desa bangko makmur dan desa bangko lestari yang berjudul' Pemanfaatan Potensi Lokal Buah Nanas Bagi Ibu-Ibu Rumah Tangga Buruh Tani Sawit Untuk Meningkatkan Perekonomian Keluarga Di Kecamatan Bangko Pusako Kabupaten Rokan Hilir' sangat mendapat respon yang positif, baik itu dari ibu camat,ibu-ibu ketua PKK di masing-masing desa serta peserta ibu-ibu buruh tani sawit dan remaja putri. Program ini sangat membuka wawasan dan serta ideide baru bagi para peserta dalam melakukan pemanfaatan potensi lokal buah nanas yang bisa menghasilkan 
pendapatan untuk meningkatkan kesejahteraan keluarga mereka. Dalam proses kegiatan pengabdian yang berlangsung ditemukan beberapa gagasan yaitu:

- Perlu dilakukan pelatihan lebih lanjut

- Perlu dilakukan pelatihan terkait pemasaran potensi buah lokal yang baik

- Perlu dibentuk pengelolaan yang lebih efektif terkait struktur organisasi pengelolaan potensi lokal buah nanas

- Pelatihan pengemasan produk

- Pelatihan pengolahan buah nanas lainnya

- Perencanaan keuangan organisasi

- Jangkauan semua desa yang ada di kecamatan bangko pusako

Harapannya program ini bisa berlanjut di tahun berikutnya sehingga apa yang menjadi gagasan dan kegiatan pada tahun ini bisa lebih dikembangkan di tahun berikutnya. Impian untuk menjadikan desa binaan juga akan terwujud.

\section{DAFTAR PUSTAKA}

Agbulu, N.O dan Obiyai, K. K. 2011. Development of Entrepreneurship Skill Training Module for Youths Participation in Fish Preservation and Marketing Occupation. Asian Journal of Agricultural Sciences, 3(2).

Agus, Sartono. 2002. Manajemen Keuangan: Teori dan Aplikasi, Edisi keempat, cetakan pertama. penerbit: BPFE, Yogyakarta

Baridwan, Zaki. 2004. Intermediate Accounting, Edisi delapan. Penerbit: BPFE, Yogyakarta.

Darsono, dan Ashari. 2005. Pedoman Praktis Memahami Laporan Keuangan, edisi pertama. Penerbit: Andi. Yogyakarta.

Handayani, M.Th. dan N. W. T. Artini. 2009. Kontribusi Pendapatan Ibu Rumah Tangga Pembuat Makanan Olahan Terhadap Pendapatan Keluarga. Piramida Jurnal Kependudukan dan Pengembangan Sumber Daya Manusia, $\mathrm{V}(1)$.

Http://www.agrowindo.com/peluang-usaha-budidaya-nanas-dan-analisa-usahanya.htm

Http://putracenter.net/2008/12/23/definisikewirausahaan-entrepreneurship-menurut para-ahli/

Harahap, S. Syafri. 2001. Teori Akuntansi Edisi Revisi. Jakarta: PT Raja Grafindo Persada.

Harahap, Sofyan, Syafri. 2002. Analisis Kritis Atas Laporan Keuangan. Jakarta: PT. Raja Grafindo Persada.

Hartantyo, Heru dan Romatan Alex Y. 2011. Resume Laporan Keuangan I: Income Statement. Jakarta.

Ikatan Akuntan Indonesia, dan Standar Akuntansi Keuangan. 2009. Penerbit: PT. Salemba Empat, Jakarta

Kasmir. 2009. Analisis Laporan Keuangan. Jakarta: Rajawali Pers.

Pasal 1 angka 24 Undang-Undang Republik Indonesia Nomor 23 Tahun 2014 tentang Pemerintahan Daerah.

Penjelasan Umum Peraturan Pemerintah Nomor 17 Tahun 2018 tentang Kecamatan

Warsono, 2003, Manajemen Keuangan Perusahaan, Jilid Satu, edisi ketiga, penerbit Bayumedia, Jakarta. 